\title{
Literatura:
}

1. Grafsky V. G. Ogólna historia prawa i państwa: Podręcznik dla uniwersytetów. Moskwa, 2003, 744 s.

2. Międzynarodowe prawo prywatne / red. Dmitrieva G.K. 2nd ed., Poprawione i uzupełnione. Moskwa. 2004, 688 s.

3. Druzhchenko Yu.M. Główna doktryna immunitetu państwa // Czasopismo Uniwersytetu Prawa w Kijowie: ukraińskie naukowo-teoretyczne czasopismo / Kijowski Uniwersytet Prawa Narodowej Akademii Nauk Ukrainy, In-t of Powers and Laws. V.M. Korecka Narodowa Akademia Nauk Ukrainy. Kijów, 2010, S. 317-320.

DOI https://doi.org/10.30525/978-9934-26-074-2-74

\section{ПРАВОВА РЕГЛАМЕНТАЦІЯ ЗАХОДІВ ЄС ЩОДО ОБМЕЖЕННЯ СВОБОДИ ПЕРЕСУВАННЯ В УМОВАХ ПАНДЕМІЇ COVID-19}

\author{
Вериженко Д. I. \\ студентка III курсу \\ Університету державної фіскальної служби Украӥни \\ Гончаренко М. В. \\ студентка III курсу \\ Університету державної фіскальної служби України \\ Кот Ю. В. \\ студентка II курсу \\ Університету державної фіскальної служби України \\ м. Ірпінь, Київська область, Украӥна
}

Світ зіткнувся 3 безпрецедентною кризою, основу якої заклала надзвичайна ситуація в сфері охорони здоров'я. Пандемія COVID-19 глобальний виклик для держав, який потребує термінових, глобальних заходів з боку міжнародного співтовариства. У зв'язку з великою кількістю хворих на коронавірус та зважаючи на стрімке поширення хвороби, більшість держав світу здійснили низку профілактичних та протиепідемічних заходів із запобігання поширенню COVID-19. Серед них - здійснення додаткових обмежень деяких груп прав (економічних, соціальних і культурних тощо). Так, в межах Європейського Союзу було 
застосовано заходи щодо обмеження свободи пересування в умовах пандемії COVID-19. Зокрема, Рада СC ухвалила ряд рекомендацій щодо здійснення заходів обмеження свободи пересування.

В цій ситуації видається важливим визначити, наскільки ці обмеження $\epsilon$ допустимими, чи відповідають вони встановленим нормами міжнародного права критеріям. Ще у травневій заяві 2020 року Ради Європейського Союзу згадано, що «за надзвичайних обставин міжнародне право прав людини дозволяє державам обмежувати певні права людини за умови, що заходи $є$ необхідними, пропорційними, тимчасовими за своєю суттю та недискримінаційними» [1].

Ситуація у світі з COVID-19 (після оголошення BOO3 спалаху цієї хвороби пандемією) фактично засвідчила наявність цих надзвичайних обставин, як можливої підстави для запровадження таких обмежень. В зазначених умовах основним завданням всіх країн став пошук «потрібного балансу між охороною здоров'я, запобіганням економічних i соціальних збоїв і повагою прав людини» [2]. Тому спробуємо на прикладі права на свободу пересування проаналізувати, як країнамчленам СС вдається на практиці реалізувати це складне завдання.

Право свободи пересування регламентується низкою міжнародних угод різного рівня. Так, Загальна Декларація прав людини 1948 року, зокрема стаття 13, декларує, що «кожна людина має право вільно пересуватися і обирати собі місце проживання у межах кожної держави» [3]. Протокол № 4 до Конвенції про захист прав людини і основоположних свобод встановлює, що кожен, хто законно перебуває на території будь-якої держави може вільно обирати місце проживання у межах цієї території [4].

Рада Європейського Союзу в жовтні 2020 року прийняла рекомендацію щодо скоординованого підходу до обмежень вільного пересування у відповідь на пандемію COVID-19. Зазначимо, що при цьому Рада наголосила, що заходи, які будуть здійснені стосовно обмеження свободи пересування мають бути пропорційними та недискримінаційними. Окремо підкреслено, що вони мають бути негайно скасовані, коли епідеміологічна ситуація нормалізується. Такі застереження засвідчують неухильне дотримання регіональних нормативних вимог стосовно критеріїв допустимості обмежень, що вводяться.

Відповідно до згаданої Рекомендації на держав-членів покладається обов’язок надавати Свропейському центру з профілактики та контролю захворювань (ECDC) таку інформацію: 1) дані, щодо кількості нових випадків COVID-19 на 100000 населення за останні 14 днів; 2) дані, щодо здійснених тестів на 100000 населення за останній тиждень; 3) дані, щодо відсотку позитивних тестів за останній тиждень.

На основі отриманих статистичних відомостей ECDC формує зонування регіонів держав-членів на зелену, помаранчеву, червону та сіру 
зони. Відповідно до позначення регіону, держави-члени не можуть обмежувати свободу пересування осіб до зеленої зони або з неї. Стосовно країн, що потрапили в зони, позначені іншими кольорами, держави отримали право на запровадження певних обмежень щодо осіб, які бажають в'їхати на їх територію із цих зон. Маються на увазі такі обмеження як карантин або здійснення тестування після прибуття [5]. Але відзначимо, що Рекомендації Ради СС не є юридично обов'язковим документом, і тому остаточне рішення використовувати їх чи ні залишається на розсуд та відповідальність держав-членів.

Зважаючи на стрімкий розвиток пандемії, 1 лютого 2021 року Рада ЄС представила оновлені рекомендації стосовно заходів, що впливають на вільне пересування. Одним із найважливіших є запровадження нової епідеміологічної зони - темно червоної. Тепер таким кольором позначаються регіони 3 найвищим рівнем захворюваності. Тобто ті зони, в яких показники хворих на COVID-19 за 14 днів складають 500 осіб на 100000 людей i більше. Також серед рекомендацій зазначено, що держави-учасниці мають по можливості обмежити всі не важливі пересування та подорожі до червоних та темно червоних зон, але не перешкоджати руху планових перевезень. Темно червона зона підпадає під такі ж обмеження пересування як і червона, тобто при виїзді з неї, особа має здати тест на COVID-19, а після прибуття в місце призначення, відправитися на карантин або самоізоляцію. Крім того, через високий відсоток захворюваності та швидке розповсюдженню COVID-19 державам рекомендується проведення аналогічних заходів і щодо подорожуючих з помаранчевих та сірих зон.

В рекомендації також приділено увагу пересуванню осіб, що живуть біля кордонів різних епідеміологічних зон. Наголошується, що пересування таких осіб, з причин навчання, роботи або сімейних обставин, не може бути ускладнене проходженням тестів або карантину. Як бачимо, до цієї категорії населення, карантинні обмеження, що стосуються свободи пересування, не застосовуються. Передбачений виняток цілком зрозумілий, і може бути оцінений як виправданий. В іншому випадку життя згаданої групи осіб було б фактично повністю паралізовано. Проте запровадження обмежень свободи пересування залишається актуальним в складних умовах сьогодення [6].

Отже, можна зробити висновок, що правова регламентація здійснення заходів в СС щодо обмеження свободи пересування в період пандемії COVID-19 проводиться належним чином: $Є$ С стрімко реагує на зміну епідеміологічної ситуації та запроваджує нові заходи. Однак, надані Рекомендації державам-учасницям не $\epsilon$ обов'язковими, внаслідок чого, держави на власний розсуд вирішують, здійснювати заходи, запропоновані інституційною структурою ЄС чи ні. 


\title{
Література:
}

1. European Council of the European Union. URL: https://www.consilium.europa.eu/en/press/press-releases/2020/05/05/ declaration-by-the-high-representative-josep-borrell-on-behalf-of-eu-onhuman-rights-in-the-times-of-the-coronavirus-pandemic/

2. ВООЗ пояснила причини оголошення пандемії COVID-19. URL: https://www.slovoidilo.ua/2020/03/12/novyna/svit/vooz-poyasnylaprychyny-oholoshennya-pandemiyi-covid-19

3. Загальна декларація прав людини від 10 грудня 1948 року. Офіційний вісник України. 2008. № 93. Ст. 3103.

4. The Council Of Europe, Protokol №4 to the Convention for the protection of human rights and fundamental freedoms. 02 May 1968. URL: https://zakon.rada.gov.ua/laws/show/994_059\#Text.

5. European Council of the European Union. Draft Council Recommendation on a coordinated approach to the restriction of free movement in response to the COVID-19 pandemic 2020/0256. 12 October 2020. URL: https://data.consilium.europa.eu/doc/document/ST-11689-2020

6. European Council of the European Union. Council Recommendation amending Council Recommendation (EU) on a coordinated approach to the restriction of free movement in response to the COVID-19 pandemic 2021/0021. 28 January 2021. URL: https://www.consilium.europa.eu/media/ 48122/st05716-en21-public.pdf.

DOI https://doi.org/10.30525/978-9934-26-074-2-75

\section{TURKEY - EU: A LONG WAY TO NOWHERE?}

\author{
Halan V. O. \\ Ph.D. in Law,
} Associate Professor at the International Law Department

Yaroslav Mudriy National Law University, Kharkiv

Maryniv I. I.

Ph.D. in Law, Associate Professor at European Union Law Department Yaroslav Mudriy National Law University, Kharkiv

The history of European integration contains many examples of practical implementation with varying degrees of success. Over the centuries, various attempts have been made to unite such dissimilar but identical peoples of the 